\title{
Effectiveness of Beetroot (Beta Vulgaris L) Extracts On Blood Pressure Level Among Postpartum Mothers With Hypertension
}

\author{
Merisa Restiani Arma*, Ta'adi, Sri Sumarni \\ Poltekkes Kemenkes Semarang, Semarang, Indonesia \\ *merisarestiania@gmail.com
}

\begin{abstract}
Hypertension is the most common medical problem encountered in pregnancy to postpartum period and remains one of the most common causes of maternal death. High nitrate content of beetroot as well as potassium and flavonoids of celery may lower blood pressure.

The study was a Quasy-experimental control group pretest-posttest design. A total sample of 30 postpartum mothers with hypertention was enrolled in the study and randomly assigned to the 2 groups. Subjects in the beetroot extract group (BG) received beetroot extract plus usual hospital care while subjects in the control group (CG) received only the usual hospital care. All subjects in each groups kept on their antihypertensive medicine. Data were statistically evaluated using Paired Sample T-test, Independent Sample T-test.

The consumption of beetroot extract decreased systolic BP $27,40 \mathrm{mmHg}$ and diastolic BP 13,47 mmHg. Meanwhile in CG, BP was reduced by $8,40 \mathrm{~mm} \mathrm{Hg}$ for systolic and $10,53 \mathrm{~mm} \mathrm{Hg}$ for diastolic. There was a difference in mean decrease systolic BP between the intervention and control group $(\mathrm{p}<0.05)$. There was no differences in mean diastolic BP between the intervention and control group ( $\mathrm{p}>0.05)$.

Beetroot extract are effective in reducing blood pressure among postpartum mother with hypertension. It can be used as a complementary or non-pharmacological therapy to lower BP without worrying about side effects.
\end{abstract}

Keywords : Beetroot, Hypertension, Blood Pressure, Postpartum

Received June 10, 2020; Revised June 28, 2020; Accepted August 14, 2020 


\section{STRADA Jurnal Ilmiah Kesehatan}

DOI: $10.30994 /$ sjik.v9i2.356

ISSN: 2252-3847 (print); 2614-350X (online)

Vol.9 No.2 November 2020 Page.678-685

\section{BACKGROUND}

Maternal mortality rate is one indicator to look at the degree of women's health, especially on success in maternal health efforts. The high maternal mortality rate is caused by various factors. The main causes of maternal death are hypertension, bleeding, and infection. Hypertension is one of the most common complications during pregnancy and is the second largest cause of maternal death after bleeding [USAID, 2017]. Postpartum hypertension is a common cause of concern, similar to hypertension in the antepartum period. Hypertension that continues into the postpartum period can threaten well-being to death [Hwang, 2015]. At least 25\% of the incidence of chronic hypertension and $35 \%$ of gestational hypertension can develop into preeclampsia [Ryan, 2018]. This certainly needs to be a concern considering preeclampsia has the highest risk of complications [Magee, 2018].

Women with a history of hypertension in pregnancy have a high risk of experiencing eclampsia or seizures at the onset of postpartum, which is most often within 48 hours after delivery. Blood pressure decreases after birth, but will increase in 3-6 days postpartum due to the mobilization of large volumes of sodium and water into the intravascular section during labor [Sharma, 2017]. It is important to identify women who need antihypertensive treatment in the early postpartum period to prevent secondary complications such as stroke, pulmonary edema or kidney failure [Asali, 2019].

Management of hypertension in postpartum mothers who are usually given with pharmacological therapy of Nifedipine $10 \mathrm{mg}$. Nifedipine taken with the right dosage is proven to reduce blood pressure, but this drug can cause side effects such as flatulence, contipation, nausea, cough, and headache [Burnier, 2017].

Alternative or complementary therapies need to be considered to address the side effects of Nifedipine. Nutrition and lifestyle-based interventions are recognized as important strategies for primary prevention and as an alternative to non-pharmacological management in managing hypertension [Siervo, 2013].

Beetroot have long been known as super food because they have many healthbeneficial ingredients such as carotenoids, nitrates, flavonoids, vitamins, minerals such as potassium / sodium, phosphorus, calcium, magnesium, copper, iron, zinc, manganese, sodium, and betalain (betasianin) [11,12]. Beetroot (Beta vulgaris L) has a high inorganic nitrate content, usually ranging from 110 to $3670 \mathrm{mg} / \mathrm{kg}$ [Siervo, 2013].

Beetroot have the potential for additional treatment in several clinical conditions. There have been many studies of beetroot as a therapeutic intervention for hypertension [Jajja, 2014]. Beetroot juice administration has been shown to reduce daily systolic blood pressure after 3 weeks in the elderly, with an average decrease of $-7.3 \pm 5.9 \mathrm{~mm} \mathrm{Hg}$ and Pvalue $=0.02$ [Jajja, 2014]. Similar results were found in the study Berry et al, which states that administration of beetroot juice can reduce diastolic blood pressure by an average of 6.4 and $5.6 \mathrm{mmHg}$ and an average systolic blood pressure of $8.2 \mathrm{mmHg}$ in patients with chronic obstructive pulmonary disease [Berry, 2015].

Herbal treatments are increasingly in demand because of the minimum side effects, and the development of research on herbal treatments is also growing [Saputra, 2016]. This is supported by the availability of herbal base ingredients which are high in nature so that they have the potential to be developed as an alternative treatment [Syahidah, 2018]. 


\section{STRADA Jurnal Ilmiah Kesehatan}

DOI: $10.30994 /$ sjik.v9i2.356

ISSN: 2252-3847 (print); 2614-350X (online)

Vol.9 No.2 November 2020 Page.678-685

\section{METHODS}

This study uses an experimental Quasy design with a Pretest-posttest with control group design approach. The independent variables in this study are beetroot extract and the dependent variable is systolic and diastolic blood pressure.

The poupulation in this research is all postpartum hypertension mothers in Bhakti Wira Tamtama Hospital Semarang City, amounting to 162 people. The sample in this study amounted to 30 people who were divided into two groups: 15 people in the intervention group and 15 people in the control group.

Sampling was done by randomized sampling technique by giving lottery numbers to respondents who had previously been screened based on inclusion criteria: postpartum mothers with grade I hypertension (TD> 140/90 $\mathrm{mmHg}$ ), postpartum mothers in full awareness, domiciled in the Semarang City Region.

The intervention group was given $1000 \mathrm{mg}$ beetroot doses with a frequency of $1 \mathrm{x}$ a day and nifedipine POR drugs for 7 days, beetroot extract taken 3 hours after nifedipine POR drugs, while the control group was only given nifedipine POR drugs. All respondents had previously given their consent and were willing to participate in this research voluntarily. This study was approved by the ethics committee of the Moewardi Hospital Surakarta with ethical license number 057 / I / HREC / 2020.

The instrument used to measure blood pressure is a digital sphygmomanometer. Data analysis uses univariate and bivariate analysis using Paired Sample $T$ Test and Independent Samples T Test.

\section{RESULTS}

1. Descriptive Analysis of Systolic and Diastolic Blood Pressure in the Celery Beet Extract Combination Group, Beet Extract Extract and Control Group

Table 1

Systolic and Diastolic Blood Pressure Frequency Distribution In the Intervention and Control Groups

\begin{tabular}{clcc}
\hline & \multicolumn{1}{c}{ Variable } & Mean \pm SD & Min-Max \\
\hline \multirow{4}{*}{ Group } & TD Systolic & & \\
Intervention & Pretest & $152.53 \pm 10.99$ & $140 \pm 175$ \\
& Posttest & $125.13 \pm 7.15$ & $110 \pm 141$ \\
& Diastolic BP & & \\
& Pretest & $95.80 \pm 8.19$ & $83 \pm 115$ \\
& Posttest & $82.33 \pm 3.86$ & $77 \pm 90$ \\
\hline \multirow{3}{*}{ Group } & TD Systolic & & \\
Control & Pretest & $149.80 \pm 9.60$ & $140 \pm 170$ \\
& Posttest & $141.40 \pm 8.06$ & $128 \pm 154$ \\
& Diastolic BP & & \\
& Pretest & $97.27 \pm 6.40$ & $85 \pm 112$ \\
& Posttest & $86.73 \pm 4.72$ & $80 \pm 95$ \\
\hline
\end{tabular}

* descriptive

The table above shows that the results of measuring systolic and diastolic blood pressure in the two groups decreased between pretest and posttest. In the beet extract group the mean pretest systolic BP value was $152.53 \pm 10.993$ with a minimum value of $140 \mathrm{mmHg}$ with a maximum value of $175 \mathrm{mmHg}$ and the post-test BP value decreased 


\section{STRADA Jurnal Ilmiah Kesehatan}

DOI: $10.30994 /$ sjik.v9i2.356

ISSN: 2252-3847 (print); 2614-350X (online)

Vol.9 No.2 November 2020 Page.678-685

to $125.13 \pm 7.150$ with a minimum value of $110 \mathrm{mmHg}$ to a maximum value of 141 $\mathrm{mmHg}$. , then the pretest diastolic BP value was $95.80 \pm 8.19$ with a minimum value of $83 \mathrm{mmHg}$ with a maximum value of $115 \mathrm{mmHg}$ and the posttest BP value decreased to $82.33 \pm 3.86$ with a minium value of $77 \mathrm{mmHg}$ to a maximum value of $90 \mathrm{mmHg}$.

Likewise in the control group, the mean pretest systolic BP was $149.80 \pm 9.601$ with a minimum value of $140 \mathrm{mmHg}$ with a maximum value of $179 \mathrm{mmHg}$ and a posttest systolic BP of $141.40 \pm 8.069$ with a minimum value of $128 \mathrm{mmHg}$ with a maximum value of $154 \mathrm{mmHg}$, then pretest diastolic BP $97.27 \pm 6.408$ with a minimum value of $85 \mathrm{mmHg}$ with a maximum value of $112 \mathrm{mmHg}$ and posttest $86.73 \pm 4.728$ with a minimum value of $80 \mathrm{mmHg}$ to $95 \mathrm{mmHg}$.

Decreased blood pressure in each group can be seen in the graph below:

Graph 1

Changes in Systolic Blood Pressure in Each Group

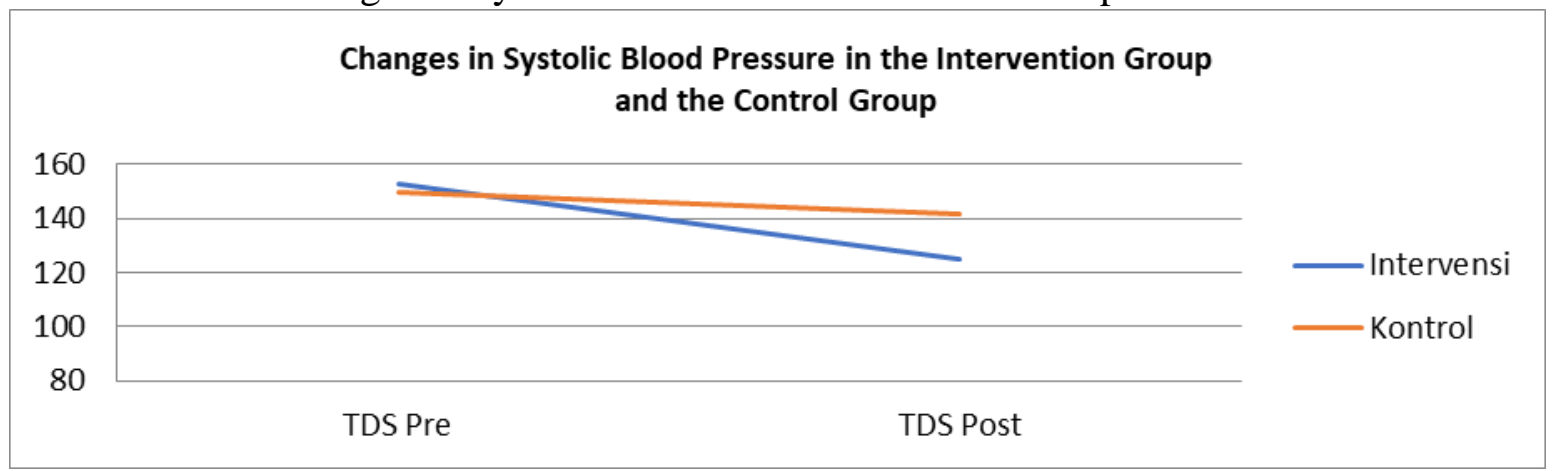

Graph 2

Changes in Diastolic Blood Pressure in Each Group

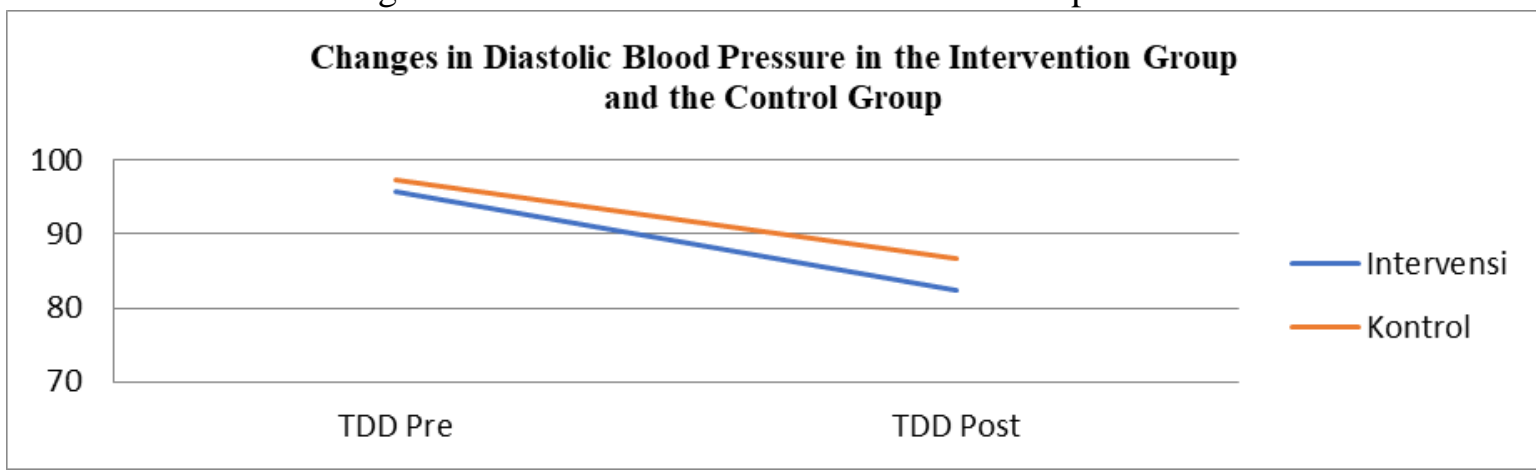

2. Analysis of differences in systolic and diastolic blood pressure before and after the intervention in the intervention group and the control group 


\section{STRADA Jurnal Ilmiah Kesehatan}

DOI: $10.30994 /$ sjik.v9i2.356

ISSN: 2252-3847 (print); 2614-350X (online)

Vol.9 No.2 November 2020 Page.678-685

Table 2

Differences in systolic and diastolic blood pressure values before and after the intervention in each group

\begin{tabular}{lcccc}
\hline & \multirow{2}{*}{ Variable } & \multicolumn{2}{c}{ Intervention Group } & \multicolumn{2}{c}{ Control group } \\
\cline { 2 - 5 } & The mean & $* \boldsymbol{\rho}$ & The mean & $* \boldsymbol{\rho}$ \\
\hline TD Systolic & & & & \\
Pretest & 152.53 & .001 & 149.80 & 0.002 \\
Posttest & 125,13 & & & \\
\hline Diastolic BP & & & & \\
Pretest & 95.80 & .001 & 97.27 & .001 \\
Posttest & 82.33 & .001 & 86.73 & .001 \\
\hline
\end{tabular}

* Paired Sample T Test

Based on table 2 which shows the results of paired sample t-test, systolic and diastolic blood pressure in each group, namely the beetroot extract intervention group, and the control group both have $\rho$-values $<0.05$, which means that there are differences significant in the mean decrease in systolic blood pressure in both groups between pretest and posttest.

In the intervention group the beetroot extracts of pretest systolic blood pressure with a mean of $151.33 \mathrm{mmHg}$ included in the stage I hypertension category, experienced a mean decrease at posttest with a mean of $125.00 \mathrm{mmHg}$ included in the pre hypertension category. Likewise with diastolic blood pressure which also showed a decrease from pretest with a mean of $95.73 \mathrm{mmHg}$ in the stage I category of hypertension, a decrease in the mean to posttest with a mean of $82.00 \mathrm{mmHg}$ which was included in the category of pre hypertension. In the control group the pretest systolic blood pressure value was $149.80 \mathrm{mmHg}$ and the posttest systolic blood pressure was $141.40 \mathrm{mmHg}$ then the pretest diastolic blood pressure was $97.27 \mathrm{mmHg}$ and $86.73 \mathrm{mmHg}$ posttest.

\section{Analysis of differences in systolic and diastolic blood pressure in each intervention group and control group}

Table 3

Differences in systolic and diastolic blood pressure values in groups intervention and control group

$\begin{array}{cccc}\text { Variable } & \text { Intervention Group } & \text { Control group } & \begin{array}{c}\text { Sig. } \\ \text { (2-tailed) }\end{array} \\ & \text { Mean } \pm \text { SD } & \text { Mean } \pm \text { SD } & \\ \text { TD Systolic } & 27.40 \pm 8.765 & 8.40 \pm 8.749 & .001 \\ \text { Diastolic BP } & 13.46 \pm 7.763 & 10.53 \pm 6.413 & 0.269\end{array}$

*Independent Sample T Test

Based on the results of the analysis of the Independent sample $t$ test for the difference in systolic blood pressure reduction in the beetroot extract intervention group and the control group, the Sig (2-tailed) value of $0.001(\mathrm{p}<0.05)$ means that there is a significant difference between the intervention group and control group. Then, the difference in the decrease in diastolic blood pressure in the intervention group and the 


\section{STRADA Jurnal Ilmiah Kesehatan}

DOI: $10.30994 /$ sjik.v9i2.356

ISSN: 2252-3847 (print); 2614-350X (online)

Vol.9 No.2 November 2020 Page.678-685

control group was obtained Sig. (2-tailed) 0.269 ( $p>0.05$ ) which means there were no significant differences between the intervention group and the control group.

\section{DISCUSSION}

Intervention of beetroot extracts and nifedipine POR to 15 respondents for 7 days showed the results of a decrease in systolic and diastolic blood pressure in postpartum hypertensive mothers. The results of systolic and diastolic blood pressure measurements in the intervention group and the control group experienced a decrease between pretest and posttest. However, the intervention group of beetroot extracts had a mean decrease more than the control group.

This is in line with the study of beetroot juice supplementation for 24 hours showing the results of a decrease in systolic blood pressure of $5 \mathrm{mmHg}$ and diastolic 3-4 $\mathrm{mmHg}$ [ McDonagh, 2018]. Nitrates present in beetroot will help increase the production of nitric oxide (NO), which is a molecule involved in vasodilation of arteries and blood vessels and causes blood vessels to dilate or dilate. When blood vessels dilate means more blood flow throughout the body and this can help reduce heavy heart work [Siervo, 2013].

Poor lifestyle and low intake of fruits and vegetables can be a risk factor for high blood pressure [Ocampo, 2018]. Therefore, the increase in consumption of fruits and vegetables can be a preventive measure against hypertension and cardiovascular disease. Epidemiological studies have shown certain food groups such as green leafy vegetables in addition to preventing high blood pressure also have the greatest protection against coronary heart disease and the risk of ischemic stroke [Hobbs, 2012]. Based on research DASH (Dietary Approaches to Stop Hypertension) states that consuming foods that are high in potassium and fiber, and high inorganic nitrates are highly recommended for lowering blood pressure [Berawi, 2018] Beet tubers (Beta vulgaris L) are included in the list of DASH diet vegetables [Olumese, 2017]

Herbal is one of the efforts to reduce blood pressure or hypertension treatment in a complementary manner without any side effects [Oktavia, 2017]. Increased consumption of fruits and vegetables can be a preventative measure against hypertension and cardiovascular disease [Hobbs, 2012].

In this study beetroot extract acts as a potential complementary alternative therapy together with nifedipine, given simultaneously with different actions, then gives a greater effect on patients if given together rather than each effect separately. This is in line with the Complementary and Alternative Medicine (CAM) approach which is supported by clinical studies and meta-analysis to reduce blood pressure by utilizing natural herbs [Zhang, 2015].

Beetroot has been known to have many ingredients that are very beneficial for health, besides beetroot is safe for consumption and has no harmful effects on the body. Based on the results of toxicological studies on beetroot conducted in healthy mice to find out the toxic and safety effects of beetroot extraction supplementation, it has been known that oral doses for 4 weeks were found to have no harmful effects and the mice remained healthy with normal weight gain [Nisa, 2015].

Beetroot are a type of vegetable that is classified as having a high content of nitrate (NO3) which has health benefits, such as improved endothelial function [Baião, 2016]. Several experimental and clinical studies show that nitrate supplementation can increase the bioavailability of nitric oxide. Inorganic nitrate can prevent increased sympathetic nerve activity in experimental models of hypertension induced Ang II (angiotensin II) [Guimarães et al, 2019]. 


\section{STRADA Jurnal Ilmiah Kesehatan}

DOI: $10.30994 /$ sjik.v9i2.356

ISSN: 2252-3847 (print); 2614-350X (online)

Vol.9 No.2 November 2020 Page.678-685

Nitrate supplementation normalizes the expression of AT 1 Rs (Ang II type-1 receptor) in the rostral ventrolateral medulla and reduces sympathetic nerve activity, which is associated with weakening the development of hypertension through a mechanism that involves reducing sympathetic flow [Guimarães et al, 2019]. Beetroot has been used in traditional medicine throughout the world. Many studies have indicated that increased consumption of food plants such as beetroot reduces the risk of obesity, diabetes mellitus, and cardiovascular disease, beneficial for the treatment of cancer and protection against heart disease[Baião, 2016].

\section{CONCLUSION}

Based on the results of data analysis and discussion, the conclusion of this study is that 1000mg of beet root extract for 7 days is effective in reducing systolic and diastolic blood pressure in hypertensive postpartum mothers.

\section{REFERENCE}

USAID, "Role of Nutrition in Ending Preventable Child and Maternal Deaths," vol. 2004, pp. 1-9, 2017.

JW Hwang et al., "The risk factors that predict chronic hypertension after delivery in women with a history of hypertensive disorders of pregnancy," Med. (United States), vol. 94, no. 42, p. e1747, 2015.

RM Ryan and FP McCarthy, "Hypertension in pregnancy," Obstet Gynaecol. Reprod. Med, vol. 28, no. 5, pp. 141-147, 2018.

LA Magee and P. von Dadelszen, "State-of-the-Art Diagnosis and Treatment of Hypertension in Pregnancy," Mayo Clin. Proc., vol. 93, no. 11, pp. 1664-1677, 2018.

KJ Sharma and SJ Kilpatrick, "Postpartum Hypertension: Etiology, Diagnosis, and Management," Obstet Gynecol. Surv., vol. 72, no. 4, pp. 248-252, 2017.

A. Asali, D. Ravid, N. Miller, R. Daher, O. Cohen, and A. Berkovitz, "Can we predict the need for antihypertensive treatment during the early postpartum period for women with preeclampsia or gestational hypertension?" Pregnancy Hypertens., vol. 17, no. May, pp. 133-137, 2019.

M. Burnier, "Drug adherence in hypertension," Pharmacol. Res., vol. 125, pp. 142-149, 2017.

M. Siervo, J. Lara, I. Ogbonmwan, and JC Mathers, "Inorganic Nitrate and Beetroot Juice Supplementation Reduces Blood Pressure in Adults: A Systematic Review and Meta-Analysis," J. Nutr., vol. 143, no. 6, pp. 818-826, 2013.

A. Jajja et al., "Beetroot supplementation lowers daily systolic blood pressure in older, overweight subjects," Nutr. Res., Vol. 34, no. 10, pp. 868-875, 2014.

MJ Berry et al., "Dietary nitrate supplementation improves exercise performance and decreases blood pressure in COPD patients," Nitric Oxide - Biol. Chem., Vol. 48, no. 2, pp. 22-30, 2015.

O. Saputra and T. Fitria, "Efficacy of celery leaves (apium graveolens) against high blood pressure in hypercholestrolemia patients," Majority, vol. 5, no. 2, pp. 120$125,2016$.

FM Syahidah and Rr. Sulistiyaningsih, "SEEDRI POTENTIAL (Apium graveolens) FOR TREATMENT: ARTICLE REVIEW,"Farmaka, vol. 16, no. 1, pp. 55-62, 2018. 


\section{STRADA Jurnal Ilmiah Kesehatan}

DOI: $10.30994 /$ sjik.v9i2.356

ISSN: 2252-3847 (print); 2614-350X (online)

Vol.9 No.2 November 2020 Page.678-685

STJ McDonagh, LJ Wylie, JMA Webster, A. Vanhatalo, and AM Jones, "Influence of dietary nitrate food forms on nitrate metabolism and blood pressure in healthy normotensive adults," Nitric Oxide - Biol. Chem., vol. 72, pp. 66-74, 2018.

DAB Ocampo, AF Paipilla, E. Marín, S. Vargas-Molina, JL Petro, and A. PérezIdárraga, "Dietary nitrate from beetroot juice for hypertension: A systematic review," Biomolecules, vol. 8, no. 4, pp. 1-12, 2018.

DA Hobbs, N. Kaffa, TW George, L. Methven, and JA Lovegrove, "Blood pressurelowering effects of beetroot juice and novel beetroot-enriched bread products in normotensive male subjects," Br. J. Nutr., vol. 108, no. 11, pp. 2066-2074, 2012.

KN Berawi and AV Pasya, "The Effect of Giving Sweet Star Fruit Juice (Averrhoacarambola L) to Lower Blood Pressure," Majority, vol. 5, pp. 23-27, 2016.

FE Olumese and HA Oboh, "Antioxidant and Antioxidant capacity of raw and processed Nigerian Beetroot (Beta vulgaris)," Niger. J. Basic Appl. Sci, vol. 24, no. 1 , p. $35,2017$.

H. Intan Eka Oktavia, Junaid, and Ainurafiq, "The Effect of Giving Celery (Apium Graveolens) on the Reduction of Systolic and Diastolic Blood Pressure in Patients with Hypertension in the Work Area of Puuwatu Health Center in Kendari City in 2016," JIMKESMAS (Ilh. Mhs. Kesehat. Society Journal), vol. 2, no. 6, pp. 1-12, 2017.

YQ Zhang, J. Wang, XJ Xiong, PQ Wang, SJ Li, and XK Li, "Garlic for hypertension: A systematic review and meta-analysis of randomized controlled trials," Phytomedicine, vol. 22, no. 3, pp. 352-361, 2015.

A. Nisa et al., "Nutritional, Antioxidant, Microbiological and Toxicological Studies on Red Dye Extracted from Red Beet Roots (Beta vulgaris)," Res. J. Chem. Sci., Vol. 5, no. 4, pp. 468-480, 2015.

D. Dos Santos Baião, CA Conte-Junior, VMF Paschoalin, and TS Alvares, "Beetroot juice increases nitric oxide metabolites in both men and women regardless of body mass," Int. J. Food Sci. Nutr., vol. 67, no. 1, pp. 40-46, 2016.

DD Guimarães et al., "Dietary Nitrates Reduces Blood Pressure in Rats With Angiotensin II-Induced Hypertension via Mechanisms That Involve Reduction of Sympathetic Hyperactivity," Hypertens. (Dallas, Tex. 1979), vol. 73, no. 4, pp. 839-848, 2019. 